Kamila Kowalik ${ }^{1}$, Dorota Klimecka-Tatar ${ }^{2}$

\title{
ANALYSIS AND EVALUATION OF SERVICE QUALITY, QUALITY IMPROVEMENT - CASE STUDY
}

\begin{abstract}
The objectives of the analysis conducted and described in this paper has been to present the practical application of service quality improvement's chosen methods based on case study. The first part of the article contains the theoretical framework of service quality and its improvement. Afterwards, the results of empirical research have been presented. First of all, to analyze the process, the Servqual method has been chosen. To choose the most important areas of improvement the Importance-Performance Analysis' results have been used. Furthermore, in the Impact and Effort Matrix the selected improvement ideas have been included.
\end{abstract}

Key words: Impact\&Effort Matrix, Importance-Performance Analysis, improvement, service quality, Servqual method

\section{Introduction}

Dynamic development of the service sector has been observed in recent years. Gradual intensification of competition, caused by this phenomenon, has contributed to the use of constantly new competitive fighting tools. Quality has been perceived as one of them. The main principle of modern service enterprises functioning is providing high quality of services. Service quality, as a comprehensive and complex issue has been the result of theoretical consideration of quality adapted to the specification of service process [1].

The lack of one universal description of this term has been caused by its multidimensionality [2]. The literature marks out five primary sets of service quality's characteristics. First of them, product-based approach determines service quality by the measurable attributes possessed by the service. Process-approach perceives the service quality as its compliance with the adopted standard. The opposite-demand perspective has been the most popular approach based on customer satisfaction. Service quality is defined as the meet of customers' needs and expectations that need continual observing. Philosophical definitions refers to the perfection of the service

\footnotetext{
${ }^{1}$ Mgr inż., Faculty of Management, Częstochowa University of Technology, Al. Armii Krajowej 19b, 42200 Częstochowa, Polska, e-mali: kamilakowalik93@gmail.com

${ }^{2}$ Dr inż., Department of Production Engineering and Safety, Faculty of Management, Częstochowa University of Technology, Al. Armii Krajowej 19b, 42-200 Częstochowa, Polska, e-mail: dorota.klimecka-tatar@wz.pcz.pl
} 
delivery. The last one, value-approach characterizes the quality of service as a ratio of provided benefits to acquired costs [3].

All of the theoretical considerations emphasize the high significance of quality are based on the Japanese philosophy of Kaizen which continuous improvement perceives as the basis of business practice. Improvement may be defined as regular and gradual introduction of permanent changes to all processes realizing in enterprises which aims to raising the level of quality by maximizing the effectiveness and efficiency of functioning (maximizing the benefits with minimizing the costs) [4].

\section{Experimental}

The subject of research for service quality improvement is customer service process in veterinary clinic. For the purpose of the study in this case customer service concerns the owner of the pet and includes preparatory processes for the provision of the service (making, transfer and cancel an appointment), service at reception before the visit, interaction between the vet and the owner during the visit, and service at reception after the visit.

Veterinary clinic being the subject of the study has been functioning since 2011 in the center of the one of the largest cities in the Silesian voivodeship. This service enterprise employs vets, veterinary technicians, zootechnicians, zoophysiotherapists, and groomers. It specializes mainly in the prevention and treatment of small animals (dogs, cats, rodens). The clinic delivers a wide range of services: blood tests, radiological, ultrasound and electrocardiographic examinations, vaccinations, surgical procedures, sale of veterinary diets and accessories and groomer services.

The first part of the study contains measuring the customer service quality by the Servqual method. This method, elaborated by A. Parasuraman, V.A. Zeithaml and L.L. Berry has been perceived as the most widespread method used for measuring service quality [5]. An assumption of this approach is to compare the customers' expectations and perception of the actual standard of quality service with using specially prepared questionnaire, including statements which are evaluated by customers with using a seven point Likert scale [6]. Selected for the purpose of the study statements have been grouped in five dimensions as follows [7]:

- tangibles (physical facilities, equipment, staff's appearance),

- reliability (ability to perform the service accurately and dependably),

- responsiveness (willingness to help),

- assurance (staff's knowledge and courtesy),

- empathy (staff's attention and customer understanding).

Every dimension has also its validity evaluated by each respondent. The performance quality of customer service process has been based on collected data [8]. In business practice there may be three situations [9]: 
- perceived performance=the expectations: service quality is satisfied,

- perceived performance>the expectations: service quality exceeds customers' expectations,

- perceived quality<the expectations: service quality does not meet customers' needs.

Afterwards, the collected data has been analyzed by the ImportancePerformance Analysis. This method, firstly used in 1977, has nowadays been considered as a complement of the Servqual [10]. The approach of the IPA defined satisfaction as a function of the attributes importance and the service enterprise's effectiveness by providing it [11]. Results, presented onto a two-dimensional matrix (where the y-axis is importance and the $\mathrm{x}$-axis is performance) single out where marked grades are not covered with the matrix diagonal. The lack of the correlation (high significance and low effectiveness) identify the critical areas that need improvement [12].

The most important is first quadrant that contains crucial attributes with low quality. The enterprise should maintain the quality of the attributes that are in the second quadrant. The third one contains the parameters that are not such important and their quality is low. The last area refers to loss of quality because the attributes also are not important but are rated high [13].

The ideas of improvement for identified the most important quality factors have been analysed by the Impact and Effort Matrix. This tool of improvement from Six Sigma methodology shows the impact of potential solutions on the factors that need improvement and the effort and cost that need to be incurred for their implementation $[14,15]$.

\section{Results and discussion}

In the survey participated fifty customers of the particular veterinary clinic, including 30\% males and $70 \%$ females. The structure of the respondents is shown in table 1 .

Table 1. The characteristics of respondents - percentage structure of respondents features

\begin{tabular}{|c|c|c|c|}
\hline Age & Males, \% & Females, \% & Total, \% \\
\hline $18-24$ & 6 & 2 & 8 \\
\hline $25-39$ & 16 & 38 & 54 \\
\hline $40-59$ & 4 & 22 & 26 \\
\hline $60<$ & 4 & 8 & 12 \\
\hline \multicolumn{3}{|r}{} & $\mathbf{1 0 0}$ \\
\hline
\end{tabular}


Prepared servqual questionnaire about customer service process' quality includes sixteen statements grouped to five dimensions. Customers filled two sheets of survey: the first about the validity of each area and the second about the perceived performance.

The attributes are presented in table 2.

Table 2. Attributes of the Servqual

\begin{tabular}{|c|c|c|}
\hline Dimension & Symbol & Attribute \\
\hline \multirow{4}{*}{ Tangibles } & $\mathrm{T} 1$ & modernity of equipment \\
\hline & $\mathrm{T} 2$ & attractiveness of the reception \\
\hline & T3 & staff's appearance \\
\hline & $\mathrm{T} 4$ & availability of information materials \\
\hline \multirow{4}{*}{ Reliability } & R1 & punctuality of service delivery \\
\hline & $\mathrm{R} 2$ & faultlessness of service delivery \\
\hline & R3 & staff's help in problem-solving \\
\hline & $\mathrm{R} 4$ & availability of the offer \\
\hline \multirow{4}{*}{ Assurance } & A1 & staff's competence and knowledge \\
\hline & $\mathrm{A} 2$ & staff's politeness \\
\hline & A3 & staff's trust inspiration \\
\hline & A4 & sense of security \\
\hline \multirow{3}{*}{ Responsiveness } & RP1 & efficiency of service delivery \\
\hline & $\mathrm{RP} 2$ & transmission of all the information \\
\hline & RP3 & immediate response to requests \\
\hline \multirow{4}{*}{ Empathy } & E1 & individualized treatment \\
\hline & E2 & willingness to help \\
\hline & E3 & paying attention to customers \\
\hline & E4 & customers' needs understanding \\
\hline
\end{tabular}

The results of the Servqual method shows the level of differences between the expectations and the performance for all the statements for entire research sample. Summary statistical compilation is presented in table 3 .

Table 3. Gap score

\begin{tabular}{|c|c|c|c|c|}
\hline \multirow{2}{*}{ Dimension } & Attribute & Expectation score & Perception score & Gap score \\
\hline \multirow{3}{*}{ Tangibles } & & & 4,78 & $-0,4$ \\
\cline { 2 - 5 } & $\mathrm{T} 1$ & 5,18 & 4,86 & 0,5 \\
\cline { 2 - 5 } & $\mathrm{T} 2$ & 4,36 & 5,66 & 0,62 \\
\cline { 2 - 5 } & $\mathrm{T} 3$ & 5,04 & 3,42 & $-1,46$ \\
\hline Reliability & $\mathrm{T} 4$ & 4,88 & 3,02 & $-1,94$ \\
\hline \multirow{3}{*}{ Reliability } & $\mathrm{R} 1$ & 4,96 & 6,18 & 0,12 \\
\cline { 2 - 5 } & $\mathrm{R} 2$ & 6,06 & 5,48 & $-0,36$ \\
\cline { 2 - 5 } & $\mathrm{R} 3$ & 5,84 & 4,52 & $-1,12$ \\
\hline
\end{tabular}




\begin{tabular}{|c|c|c|c|c|}
\hline \multirow{4}{*}{ Assurance } & A1 & 6,06 & 5,56 & $-0,5$ \\
\cline { 2 - 5 } & A2 & 5,84 & 6,06 & 0,22 \\
\cline { 2 - 5 } & A3 & 6,24 & 5,78 & $-0,46$ \\
\cline { 2 - 5 } & A4 & 6,26 & 6,26 & 0 \\
\hline \multirow{3}{*}{ Responsiveness } & RP1 & 6,02 & 4,68 & $-1,34$ \\
\cline { 2 - 5 } & RP2 & 5,9 & 4,24 & $-1,66$ \\
\cline { 2 - 5 } & RP3 & 5,26 & 4,24 & $-1,02$ \\
\hline \multirow{3}{*}{ Empathy } & E1 & 4,78 & 4,32 & $-0,46$ \\
\cline { 2 - 5 } & E2 & 6,14 & 5,6 & $-0,54$ \\
\cline { 2 - 5 } & E3 & 6,18 & 6,18 & $-1,82$ \\
\cline { 2 - 5 } & E4 & 6,2 & 4,38 & \\
\hline
\end{tabular}

According to the data, it should be mentioned that some gap scores are positive numbers (six of them) which means that in that cases perceived quality is better than the expectations, three of them are 0 (quality is exactly the same as the expectations for the factors) and ten of them are negative (the importance of that factors is high but Gap scores were used for calculation the average weighed servqual score (table 4) .

Table 4. Servqual score

\begin{tabular}{|c|c|c|c|c|}
\hline Dimension & $\begin{array}{l}\text { Average of } \\
\text { dimension }\end{array}$ & $\begin{array}{c}\text { Importance } \\
\text { weight }\end{array}$ & $\begin{array}{c}\text { Weighed } \\
\text { score }\end{array}$ & Average \\
\hline tangibles & $-0,19$ & 0,16 & $-0,03$ & \multirow{5}{*}{$-0,138$} \\
\hline reliability & $-0,83$ & 0,26 & $-0,21$ & \\
\hline assurance & $-0,19$ & 0,21 & $-0,04$ & \\
\hline responsiveness & $-1,34$ & 0,15 & $-0,2$ & \\
\hline empathy & $-0,94$ & 0,22 & $-0,21$ & \\
\hline
\end{tabular}

The data presented in table 3 shows a negative value of average weighed servqual score. The most general conclusion from the Servqual method is: customer expectations of the customer service have not been meeting - process should be improved. The highest weighed score concerns three dimensions: reliability (especially punctuality of service delivery and availability of the offer), responsiveness (each of the factors has similar, negative score), and empathy (particularly understanding customers' needs). It should be noted that this negative value is not high and introducing appropriate improvement activities may with big probably make this score in the next study positive.

The main factors that need improvement have been chosen with using the Importance-Performance matrix (fig. 1). 


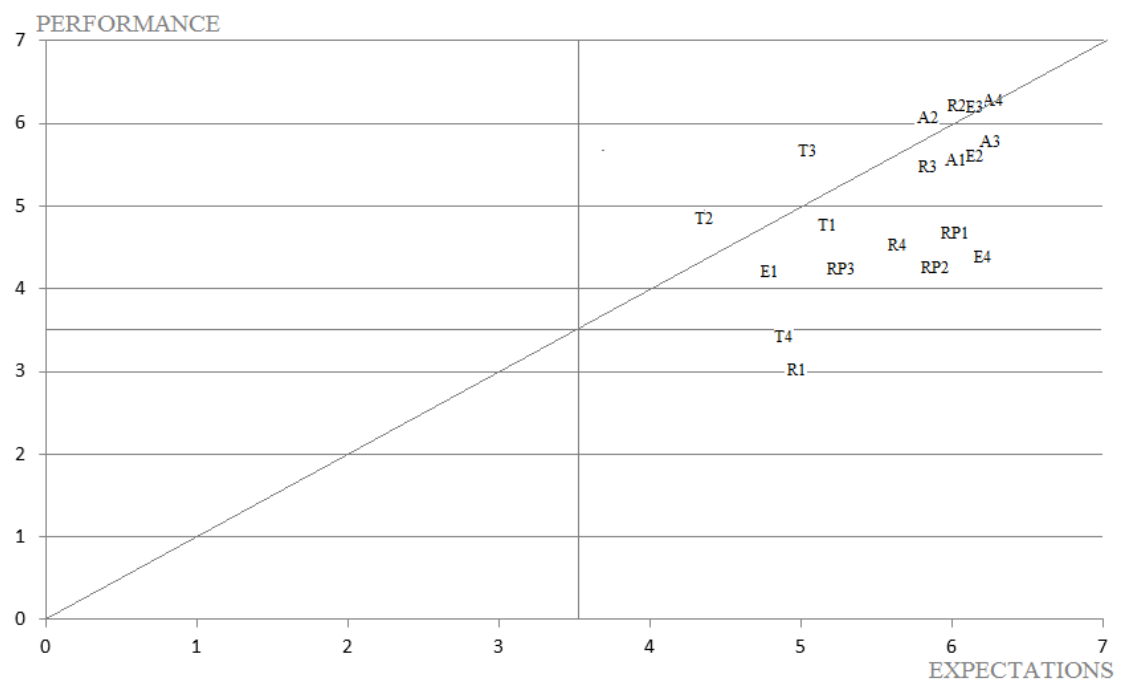

Fig. 1. The Importance-Performance Matrix

The figure shows that customers' expectations for customer service quality are very high. Simultaneously, the presence of all quality factors in the second matrix area evidences relatively good quality of actual customer service. An additional diagonal has been placed to indicate the key areas of improvement. Factors that are occurred above the diagonal exceeds customers' expectations, which are in the diagonal-mean that needs have been met, and under-should be improved (table 5).

Seven factors characterized by the highest negative difference (more than 1) are:

- punctuality of service delivery,

- customers' needs understanding,

- transmission of all the information,

- availability of information materials,

- efficiency of service delivery,

- availability of all the offer,

- immediate response to requests.

Punctuality of service delivery may be caused by prolonging previous visits (unexpected accidents, failure to adjustment of the visit time to needs, delays of previous patients) or preparation of a vet or reception (filling the patient's card, registration, cleaning after the previous visit).

Customers' needs understanding is related to subjective customers' needs, requirements or expectations. As a part of empathy dimension, in the case of customer service in veterinary clinic (as with all medical services) it is an extremely delicate issue, difficult to effective measurement and control. 
Table 5. The classification of attributes

\begin{tabular}{|c|c|c|}
\hline \multicolumn{3}{|c|}{ The assumptions for the second matrix quadrant } \\
\hline $\begin{array}{c}\text { perceived } \\
\text { performance } \\
> \\
\text { the expectations }\end{array}$ & $\begin{array}{l}\text { perceived } \\
\text { performance } \\
\qquad= \\
\text { the exectations }\end{array}$ & $\begin{array}{c}\text { perceived } \\
\text { performnce } \\
< \\
\text { the expectations }\end{array}$ \\
\hline $\begin{array}{c}\text { The current level of quality } \\
\text { must be maintained }\end{array}$ & $\begin{array}{c}\text { The current level of quality must be } \\
\text { maintained }\end{array}$ & The quality must be improved \\
\hline $\begin{array}{l}\text { - attractiveness of the } \\
\text { reception } \\
\text { staff's appearance } \\
\text {-faultlessness of service } \\
\text { delivery } \\
\text {-staff's politeness }\end{array}$ & $\begin{array}{l}\text { - sense of security } \\
\text { - paying attention to customers }\end{array}$ & $\begin{array}{l}\text {-modernity of equipment } \\
\text {-availability of information } \\
\text { materials } \\
\text {-punctuality of service delivery } \\
\text {-staff's help in problem-solving } \\
\text {-availability of the offer } \\
\text {-staff's competence and } \\
\text { knowledge } \\
\text {-staff's trust inspiration } \\
\text {-efficiency of service delivery } \\
\text {-transmission of all the } \\
\text { information }\end{array}$ \\
\hline & & $\begin{array}{l}\text {-immediate response to request } \\
\text {-individualized treatment } \\
\text {-willingness to help } \\
\text {-customers' needs understanding }\end{array}$ \\
\hline
\end{tabular}

Transmission of all the information may also be perceived in two aspects. First of them is information provided by the reception before the visit (date, time, way of preparation etc.) and after the visit (another visit). The second one concerns the interaction between the vet and the owner during the visit (diagnosis and recommendations presented in a clear and detailed manner).

Materials that customers need may be seasonal information leaflets (for example recommendations against ticks in summer, noise protection in December) or written explanation of vet's recommendations, for example dosage of medicines).

Efficiency of service delivery, according to literature research, may be related to growing customers' requirements and lifestyles of contemporary adults: customers demand meeting of their expectations quickly, ably, effective, and on time.

Availability of all the offer may concern veterinary offer (availability of medicines, treatments, and specialists) or reception offer (fodder, accessories).

Afterwards, Impact and Effort Matrix as a tool of service quality improvement has been chosen. Key factors of quality identified by Servqual and IPA's results are presented in table 6 . 


\section{Table 6. Quality factors}

\begin{tabular}{|c|l|}
\hline QF & \multicolumn{1}{c|}{ Factor } \\
\hline QF1 & punctuality of service delivery, \\
\hline QF2 & customers' needs understanding, \\
\hline QF3 & transmission of all the information, \\
\hline QF4 & availability of information materials, \\
\hline QF5 & efficiency of service delivery. \\
\hline QF6 & availability of the offer \\
\hline QF7 & immediate response to requests \\
\hline
\end{tabular}

Potential ideas of improvement for these factors may be:

- differentiation of the time of the visit during its appointment (instead of standard 30 $\min$,

- sms notification of delayed scheduled visits (I1),

- enabling e-mail to fill in the patient's card before the first visit (I2),

- adding the cancelation option to the online schedule (I3),

- introduction of the form: recommendations (paper or mail) (I4),

- sms reminder the day before the visit (I5),

- introduction of a stand with leaflets (I6),

- introduction of systematic customer satisfaction control (I7).

Impact and Effort analysis' results are presented in table 7.

The table contains selected potential solutions of the identified quality areas that need improvement with their impact of the QF meaning importance for improvement the service quality) and their effort (requirements and cost that must be incurred for their implementation).

The weights of quality factors have been taken from Servqual's weights of particular dimension (tangibles: QF4 - 0,16 - 6), reliability (QF1, QF6 - 0,26 - 9), responsiveness (QF3, QF 5, QF $7-0,15-5)$, and empathy (QF2 - 0,22- 8). Cost implementation and processing difficulty have been estimated as 6 .

Achieved outcomes have been visualized on an Impact and Effort chart (fig. 2).

The data shows that especially worth noticing are ideas: enabling e-mail to fill in the patient's card before the first visit (I2), introduction of the form: recommendations (paper or mail) (I4) and introduction of a stand with leaflets (I6). These potential improvements have impact on customer service quality (I4 the highest of them) and do not require much effort (cost and processing difficulty). Three of the propositions: sms notification of delayed scheduled visits (I1), adding the cancelation option to the online schedule (I5), and sms reminder the day before the visit (I5) should not be implemented because of their high effort. One of them, introduction of systematic customer satisfaction control is on the border between no profitability 
and consideration in terms of obtaining support. Due to the fact this idea has the highest impact of quality factors that need improvement, the authors recommend the implementation.

Table 7. Impact and Effort Analysis' results

\begin{tabular}{|c|c|c|c|c|c|c|c|c|c|c|c|}
\hline \multirow{3}{*}{$\begin{array}{r}\text { Weight } \\
\text { (importance } \\
\text { factor) }\end{array}$} & \multirow{2}{*}{ نे. } & \multirow[b]{2}{*}{ 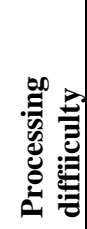 } & \multicolumn{7}{|c|}{ Impact on } & \multirow{3}{*}{ 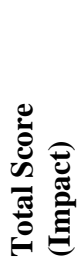 } & \multirow{3}{*}{ 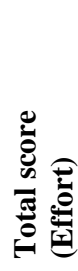 } \\
\hline & & & \multirow{2}{*}{$\begin{array}{l}\overline{0} \\
9\end{array}$} & \multirow{2}{*}{$\frac{\sqrt{2}}{8}$} & \multirow{2}{*}{$\frac{m}{5}$} & \multirow{2}{*}{$\begin{array}{l}+2 \\
6\end{array}$} & \multirow{2}{*}{$\begin{array}{l}n \\
0 \\
0\end{array}$} & \multirow{2}{*}{$\begin{array}{c}6 \\
0 \\
0\end{array}$} & \multirow{2}{*}{$\frac{\sqrt{2}}{5}$} & & \\
\hline & 6 & 6 & & & & & & & & & \\
\hline Potential imp & ven & nt idea & & & & & & & & & \\
\hline I1 & 5 & 7 & 8 & 6 & 0 & 0 & 6 & 0 & 0 & 150 & 72 \\
\hline I2 & 3 & 3 & 5 & 4 & 3 & 0 & 7 & 0 & 0 & 127 & 36 \\
\hline I3 & 6 & 4 & 4 & 5 & 0 & 0 & 5 & 3 & 0 & 128 & 60 \\
\hline I4 & 3 & 2 & 3 & 6 & 7 & 4 & 6 & 0 & 0 & 164 & 30 \\
\hline I5 & 5 & 5 & 8 & 7 & 4 & 0 & 5 & 3 & 0 & 200 & 60 \\
\hline I6 & 4 & 3 & 0 & 4 & 4 & 9 & 0 & 0 & 0 & 106 & 42 \\
\hline I7 & 5 & 6 & 2 & 9 & 4 & 4 & 8 & 3 & 3 & 216 & 66 \\
\hline
\end{tabular}

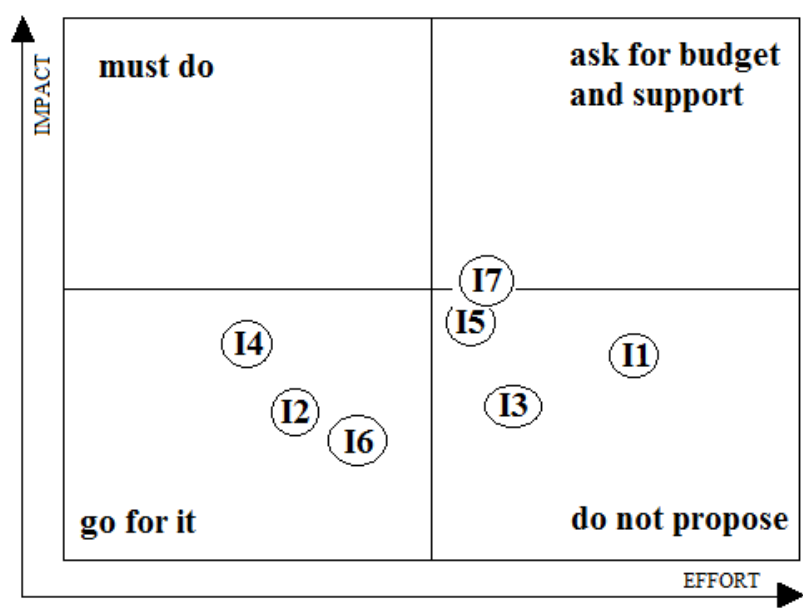

Fig. 2. The Impact and Effort chart 


\section{Conclusion}

The results presented in the paper show the practical application of chosen service quality improvement's methods for improving the quality of customer service in veterinary clinic. The most popular method of measurement of quality of services the Servqual contributed to the general conclusion, that service quality does not meet customers' requirements. Customers were not satisfied especially with punctuality of service delivery, their needs understanding, and transmission of information. The most important dimension is for them reliability of service. The results of Servqual, presented in Importance-Performance Matrix, by adding the extra diagonal, helped to identified seven key quality factors that need improvement. Selected potential improvement ideas have been analyzed by Impact and Effort matrix that pointed out three solutions that should be implemented and one of them worth further considerations. Implementation of these ideas may significantly improve the quality of customer service in this enterprise.

\section{References}

[1] Keshavarz Y., Jamshidi D., " Service quality evaluation and the mediating role of perceived value and customer satisfaction in customer loyalty" International Journal of Tourism Cities, vol. 4, no 2, pp. 220-244, Feb. 2018.

[2] Solimun, Fernandes A., " The mediation effect of customer satisfaction in the relationship between service quality, service orientation, and marketing mix strategy to customer loyalty' Journal of Management Development, vol. 37, no 1, pp. 76-87, Jan 2018.

[3] Kowalik K., Klimecka-Tatar D. Brozova S. "Service quality model based on the 4Q's model and the system approach to service quality', in Proceedings of the 2nd International Conference: Contemporary Issues in Theory and Practice of Management, 2018, pp. 236-243.

[4] Cavallone M., Magno F., Zucchi A., “ Improving service quality in healthcare organizations through geomarketing statistical tools"' The TQM Journal, vol. 29, no 5, pp. 690-704, Jun. 2017.

[5] Ladhari R. "A review of twenty years of Servqual research" International Journal of Quality and Service Sciences, vol. 1, no. 2, pp. 172-198, Jan. 2009.

[6] Rocha J., Pinto A., Batista M., Simpson J., Ambrosano G., "The importance of the evaluation of expectations and perceptions to improve the dental service quality" International Journal of Health Care Quality Assurance, vol. 30, no. 6, pp. 567-576. Mar. 2017.

[7] Yong-Pil K., Kye-Wan K., Deok-Gyun Y., "Exploration and Development of SERVQUAL” Asian Journal of Quality, vol. 4, no. 1, pp. 116-130. Jan. 2003. 
[8] Pakdil F., Kurtulmusoglu F. "Quality improvement initiatives based on customer and service provider perspectives in shopping malls" International Journal of Quality and Service Sciences, vol. 10, no. 2, pp.176-195, Feb. 2018.

[9] Kowalik K., Klimecka-Tatar D. "Identification of main areas of customer service process improving in the cinema" Archiwum Wiedzy Inżynierskiej, vol. 2, no. 1, pp. 42-44, Jun. 2017.

[10]Izadi A., Jahani Y., Rafiei S., Masoud A., Vali L., "Evaluating health service quality: using importance performance analysis" International Journal of Health Care Quality Assurance, vol. 30. no. 7, pp. 656-663. Apr. 2017.

[11] Arbore A., Bussaca B., "Rejuvenating importance-performance analysis" Journal of Service Management, vol. 22, no. 3, pp. 409-429. Jun. 2011.

[12]Eskilden J., Kristensen K., "Enhancing importance-performance analysis" International Journal of Productivity and Performance Management, vol. 55. no. 1, pp. 40-60. Jan. 2006.

[13] Ingaldi M. "Overview of the main methods of service quality analysis" Production Engineering Archives, vol. 18, pp. 54-59, Mar. 2018.

[14]Nakhai B., Neves J., "The challenges of Six Sigma in improving service quality" International Journal of Quality\&Reliability Management, vol. 26, no. 7, pp. 663683, Oct. 2009.

[15]Hensley R.L., Dobbie K., “Assesing Readiness for six sigma in service setting” Managing Service Quality, vol. 15, no. 1, pp. 82-101, Jan. 2005.

\title{
ANALIZA, OCENA I DOSKONALENIE JAKOŚCI USLUG - CASE STUDY
}

\begin{abstract}
Streszczenie: Celem artykułu jest przedstawienie praktycznego zastosowania metod doskonalenia jakości usług w oparciu o case study. Pierwsza część opracowania zawiera teoretyczne ramy jakości usług i jej doskonalenia. Następnie zaprezentowano wyniki badań empirycznych: analizę jakości usługi w oparciu o metodę Servqual, identyfikację kluczowych obszarów doskonalenia z wykorzystaniem metody Importance-Performance oraz analizę możliwości wdrożenia poszczególnych działań doskonalących poprzez ich prezentację na macierzy Impact\&Effort.
\end{abstract}

Slowa kluczowe: analiza Importance-Performance, doskonalenie, jakość usług, macierz Impact\&Effort, metoda Servqual

Date of sending the publication to the Editor: 19.06.2018

The date of the publication's acceptance by the Editorial Board: 29.07.2018 